\title{
EXPLORING THE ROLE OF SALESPERSON ATTRIBUTES AND SERVICE BEHAVIORS IN ADAPTIVE SELLING
}

\author{
See Mei (Mandy) Lo \\ HKT Limited, Hong Kong \\ Piyush Sharma \\ Curtin University, Bentley WA 6102, Australia
}

\begin{abstract}
Services organizations face ever-increasing customer demands and competition in the marketplace, especially in the face-to-face adaptive sales encounters at retail level, making it extremely important to recruit the right kind of salespeople and give them the right kind of training to serve their customers better. However, there is little prior research that combines these two perspectives in the adaptive selling context. We address this gap with a comprehensive model including four salesperson characteristics (attractiveness, communication ability, expertise and trustworthiness) as antecedents, three service performance behaviors (service manner, extra role and need identification) as mediators, and three important outcome behaviors (willingness to disclose, customer satisfaction and behavioral intentions) as consequences. We also test this model using a field-survey with actual customers in a retail setting in Hong Kong. Our findings help demystify the adaptive selling by unraveling the customer evaluation and judgment processes.
\end{abstract}

Keywords: adaptive selling; salesperson characteristics; performance behavior; willingness to disclose; customer satisfaction; behavioral intentions 


\section{INTRODUCTION}

Under current turbulent economic times, customers search for greater value and shop more carefully and deliberately; resulting in increased competition, especially in the retail and service industries, as the customers become more sophisticated and demanding (Grewal et al., 2009). Therefore, in order to maintain their competitiveness, retailers have to meet customers' needs and to differentiate themselves by offering good customer service and unique shopping experience to every customers in order to maintain long term relationship (Karmarkar, 2004).

Service organizations are unique as the services they deliver are intangible (Zeithaml et al., 1985). Service employees need knowledge and access to information to help solving customer problems, and they need to be able to deal with angry customers, even in situation where the customer is rude, the employee is exhausted, or both (Berry et al., 1994). Frontline salespersons play in important role not just in selling but also providing service, answering queries and handling complaints; in fact, they represent the organization's face to the customers during interactions known as 'moment of truth'.

In other words, the quality of service provided by the salesperson is as important as the quality of the products sold by them. Prior research and service managers have tried to identify and validate those salesperson characteristics that positively affect performance outcomes (Park and Holloway, 2003). The study of factors that drive performance of salespeople, and how these factors vary across different contexts, are essential for both researchers and managers in both sales and marketing functions (Verbeke, Dietz and Verwaal, 2011). However, there is hardly any research that studies salesperson characteristics, their performance behavior and important customer outcomes using a common conceptual framework in a single study. 
We address this important research gap by introducing a comprehensive model with four salesperson characteristics (attractiveness, communication ability, expertise and trustworthiness), three service performance behaviors (service manner, extra role and need identification) and three important outcome behaviors (willingness to disclose, customer satisfaction and behavioral intentions). We test this model using a field-survey with actual retail customers in Hong Kong.

\section{CONCEPTUAL FRAMEWORK AND HYPOTHESES DEVELOPMENT}

\section{$\underline{\text { Salesperson Characteristics }}$}

Prior research on the physical attractiveness stereotype identified general categories of variables associated with it, including social competence, intellectual competence, concern for others, integrity, and psychological stability (Eagly et al. 1991), as well as sales performance (Anderson, 1995). More recently, others argue that besides physical attractiveness, other variables may also affect sales performance, including communication ability and likeability based on social competence, perceived salesperson expertise - based on intellectual competence, and trustworthiness - based on integrity and psychological stability (Ahearne et al. 1999).

Perceived Physical Attractiveness (PPA): Physical attractiveness is defined as the extent which the salesperson is perceived by the customer as possessing an appealing and pleasing physical appearance (Ahearne et al. 1999). Gulas and McKeage (2000) argue that there is a nearly automatic tendency to categorize a person as attractive or unattractive. In fact, recent research with neuroimaging devices also shows that a high level of physical attractiveness of a stimulus face elicits different brain activity than a low level of physical attractiveness of a stimulus face (O’Doherty et al., 2003). 
Dion et al., (1972) summarize one of the most widely cited conclusions from research on physical attractiveness as, "what is beautiful is good" (p. 285). This statement links beauty and goodness to suggest the existence of a stereotype whereby physically attractive individuals are believed to possess a wide variety of positive personal qualities and successful life. Hatfield and Sprecher (1986) even wrote that "people believe good-looking people possess almost all the virtues known to humankind". Prior research uses three major theories to explain this stereotype, namely attribution, implicit personality and social categorization theories.

Perceived Communication Ability (PCA): According to Frederick and Webster (1968), selling is a communication process during which the source (firm), the communicator (salesperson), the message (presentation), and receiver (prospect) all can influence the sales outcome. Communication skills include listening to the prospect's description of problem and salesperson's ability to sense prospect's predispositions; which are important social competences that may affect sales performance (Eagly et al, 1991; Anderson, 1995). Hence, communication ability is defined as the effective presentation of one's case to customer, which involves tailoring the sales call to meet customers' needs, listening and making effective use of time, and transferring clearly the intended information to customer (Ahearne, Gruen and Jarvis, 1999).

Communication ability is particularly important for adaptive selling as salesperson should alter their sales behavior during a customer interaction or across customer interactions based on perceived information about the nature of selling situation (Weitz, Sujan and Sujan, 1986). Salespersons who gather more customer information about the prospect can customize the content and format of their messages for more effective communication (Franke and Park, 2006). Coulter and Coulter (2003) argue that both performance-related competence (e.g. competence and customization) and personality-related competence (e.g. similarity) are antecedents of trust. 
Perceived Expertise (PEX): Perceived expertise of the salesperson is defined as the extent to which a salesperson is viewed as having knowledge regarding the application and attributes of her or his product, competing products, and of the customer's business (Ahearne, Gruen and Jarvis, 1999). Prior research shows a positive influence of perceived expertise on a wide range of sales outcomes, including customer satisfaction, trust and productivity.

Perceived Trustworthiness (PTW): Trust is defined as the belief that the exchange party is able to fulfill its obligations reliably and confidently, is motivated to seek mutually beneficial gains, and will refrain from abusing the relationship (Cho, 2006, p. 26). Dwyer et al (1987) found that trust could reduce tensions and conflicts between firms, facilitate information disclosure, enhance coordination and encourage future transactions. In consumer settings, Sirdeshmukh et al. (2002) show that trust plays a critical role in building and maintaining customer-firm relationship, enhancing and maintaining customer satisfaction and loyalty.

Consumers associate trustworthiness with attributes such as competence and benevolence. Competence refers to the degree to which partners perceive each other as having the skills, abilities and knowledge for effective task performance (Smith and Barclay, 1997). Benevolence refers to the behaviors that reflect the underlying motivation to place customer's interest ahead of self-interest (Sirdeshmukh et al, 2002). Trust in an exchange partner reduces perceived risk, which in turn may lead to greater willingness of self disclosure (Cho 2006).

\section{$\underline{\text { Service performance behaviors }}$}

Personal selling is widely adopted at retail channels despite being considered a highly expensive (Roman and Martin, 2008) yet effective (Spiro and Weitz, 1990) marketing vehicle. In the sales interaction process, customers notice employee's service manner in the form of facial 
expressions, bodily gestures, tone of voice, and language (Mattila and Enz, 2002), which affect how customers evaluate their experience (Pugh, 2001). Customers who evaluate the salesperson more positively would perceive better observable employee service behavior, including service manner, need identification (Lloyd and Sheriff, 2011) and discretionary behaviors to take extrarole beyond formal role requirement to serve customer (Bettencourt and Brown, 1997).

Perceived service manner (PSM): These are behaviors that salespersons demonstrate to foster interpersonal relationships with the customers, which facilitates interaction with the customer in a friendly and enthusiastic manner (Lloyd and Luk, 2011). It relates to the congeniality dimension on the service employee's positive attitude and warm temperament, which makes them experience empathy for the customer (Winsted 2000).

Extra role behavior (ERB): These behaviors refer to service performance going beyond the call of duty to serve customers, and to contribute to service excellence to the company (Bitner 1995). Bettencourt and Brown (1997) propose that extra-role service behavior encompasses the 'little extras' and the 'spontaneous attention' that service employees direct at customers during the service encounters. Extra-role performance not only influences evaluations of salespeople (Podsakoff and MacKenzie 1994) but also overall organizational effectiveness and/or success (Podsakoff, Ahearne, and MacKenzie, 1997).

Need identification behaviors (NIB): In the adaptive selling context, salespeople need to ask relevant questions and anticipate the preferences of the customer in order to identify the most suitable product or service offering for them (Lloyd and Luk, 2011). Sharing of information between the salesperson and the customer is an integral part of this process.

Based on the above, we posit that the four attributes of salespersons, namely perceived physical attractiveness, communication ability, expertise and trustworthiness of salespersons 
have a positive impact on service manner, extra role behaviors and need identification by the salesperson, and put forth the following hypotheses:

H1 Perceived physical attractiveness is associated positively with a) perceived service manner behavior, b) extra role behavior, and c) need identification behavior.

H2 Perceived communication ability is associated positively with a) perceived service manner behavior, b) extra role behavior, and c) need identification behavior.

H3 Perceived expertise is associated positively with a) perceived service manner behavior, b) extra role behavior, and c) need identification behavior.

H4 Perceived trustworthiness is associated positively with a) perceived service manner behavior, b) extra role behavior, and c) need identification behavior.

\section{Adaptive Selling - Customer Outcomes}

Willingness to disclosure personal information (WTD): Marketers have a growing interest to acquire more knowledge about customers' preferences to better meet their needs, to enhance customer service, and to explore more opportunities to introduce new products and services (White, 2004). Deighton (1996) argues that getting more customer information would enable firms to pursue information-based relationship, and likely to achieve more efficient targeting, more tailored offerings and greater customer retention. Collins and Miller (1994) argue that self disclosure plays a central role in development and maintenance of relations.

Adaptive selling is defined as "engaging in planning to determine the suitability of sales behaviors and activities that will be undertaken, the capacity to engage in a wide range of selling behaviors and activities, and the alteration of sales behaviors and activities in keeping with situational considerations" (Sujan, Weitz, and Kumar, 1994). In the adaptive selling context, salesperson can adapt their sales message based on information provided by the customer and nature of the selling situation. Hunter and Perreault (2006) propose that salespeople will be more 
capable of practicing adaptive selling if they have more precise customer information during the interaction as it can help them customize their sales message, and recommend products and service that meet customers' specific needs. Price et al (1995) argued that self-disclosure is needed to facilitate sharing of information between the salesperson and the customer. Adaptive selling leads to strong sales performance (Boorom et al, 1998; Frank and Park 2006).

Based on above discussion, we posit that customers who evaluate the salesperson's service behavior more positively are more willing to disclose personal information during the interaction process. By knowing customers' needs, more customized services can be offered and customers would evaluate the counter experience more positively and they are more willing to engage in long term relationship with the salesperson. These evaluation and judgment processes are not tested in previous literature. Hence, the following hypotheses:

H5 Customer's willingness to disclose personal information is positively influenced by salesperson's a) perceived service manner, b) extra role, and c) need identification behavior.

Customer satisfaction (SAT): Customer satisfaction is a key outcome of buyer-seller relationships and it is influenced by perception of service quality, product quality, price, situational factors and other personal factors (Anderson and Sullivan, 1993). Rust and Oliver (1994) define satisfaction as the "customer's fulfillment response," which is an evaluation as well as an emotion-based response to a service, and also a customer's belief on the probability of a service leading to a positive feeling. We posit that salesperson's service manner, extra-role and need identification behaviors would be positively related with customer satisfaction, as follows:

H6 Customer satisfaction is positively influenced by salesperson's a) perceived service manner, b) extra role, and c) need identification behavior. 
Behavioral Intentions (BEH): Behavioral intentions such as repurchase intentions, word of mouth, loyalty and complaining behavior are important for service providers, as satisfied customer would likely stay with a company for a long period, and contribute to the profitability of the company by repeated purchase and spreading good experience to others (Zeithaml, Berry and Parasuraman 1996). We hypothesize that customers are more likely to disclose personal information to salespersons with more favorable service behaviors and this facilitates adaptive selling. Specifically, with more information about customer's needs, the salesperson can develop and deploy sales presentation tailored to characteristics of each potential customer and propose products and services that meet customers' needs and wants (Roman and Iacobucci, 2010).

H7 Customers' behavioral intentions are positively influenced by salesperson's a) perceived service manner, b) extra role, and c) need identification behavior. $<$ Insert Figure 1 about here $>$

All these hypotheses are shown graphically in Figure 1. Next we describe a field-survey based study conducted with retail shoppers in Hong Kong, to test these hypotheses.

\section{METHODOLOGY}

\section{Empirical setting}

We conducted this study at the retail outlets of a major telecom company in Hong Kong, as the frontline salespeople in these outlets not only sell products (e.g. mobile phones) and services (e.g. phone and broadband plans) but also handle customer enquiries and complaints, thus providing a broad range of customer interactions (Bettencourt and Brown, 1997). Moreover, 
in this industry, salespeople need to use adaptive selling approach in their interactions with potential customers, which means that the sales message and service offers change dynamically based on the needs and wants communicated by customers. Finally, service encounters in retail telecom outlets involve face-to-face interactions between customer and frontline salesperson, giving the customers a chance to assess the various salesperson characteristics directly.

\section{Sample and Procedure}

We randomly selected 12 retail outlets (50\% small to medium and 50\% large size) from the company's network of 60 retail outlets spread across all the districts in Hong Kong, to ensure that the responses of customers from different segments across Hong Kong could be collected. The unit of analysis in this study is a 'unique customer visit'. We collected a total of 186 completed questionnaires. Table 1 shows the sample profile.

$<$ Insert Table 1 about here $>$

We used a structured questionnaire with three parts - Part One, with general questions about the customer's current visit, such as purpose of visit, nature of products and services of interest, whether purchase was made, time spent etc.; Part Two, with questions about customer's perception about the visit experience based on the measurement scales indicated in the later section of this paper, and Part Three, with demographic information such as age, gender, education, and occupation. We first prepared an English version of the questionnaire and then translated into Chinese by one graduate student and then back-translated into English by another graduate student, both unaware about the purpose of this study and unrelated to this project. We 
found no major discrepancies between the original and back-translated versions.

The final questionnaires were dispatched to the managers of the retail shops selected for this study. To increase the reliability and generalizability of this research, we selected only those participants (customers) who interacted with the salesperson for at least 5 minutes, regardless of their visit purpose and whether real purchases were made. Upon completion of the questionnaire, each participant was given a Fast Food Coupon worth HK\$30.

\section{$\underline{\text { Scales and Measures }}$}

We included the scales used by Ahearne et al. (1999) to operationalize the four salesperson characteristics (perceived physical attractiveness, communication ability, expertise and trustworthiness $)$, using 7-point Likert-scales $(1=$ Strongly disagree to $7=$ Strongly agree $)$. Perceived employee service behavior was measured using the service manner behavior and need identification behavior scales adapted from Lloyd and Luk (2011) and extra role service behavior was adapted from Bettencourt and Brown (1997). Customer satisfaction and behavioral intentions were measured using scales developed by Ramsey and Sohi (1997), and willingness to disclose with a scale used by Cho (2006). We also included gender, age, education, visit purpose and overall impression of the shop as control variables for the customers.

\section{DATA ANALYSIS AND FINDINGS}

We used the well-established two-step process to analyze our data, testing our measurement model first and then the structural model, using Structure Equation Modeling (SEM) with AMOS 18.0. We first tested the reliability of all the measures used in this study 
using Cronbach's alpha and found all of them higher than the minimum recommended value of 0.70 (Nunnally, 1978), indicating good internal consistency among the items of each construct. We then assessed the relative fit through examination of item loadings of all factors. The results demonstrate that all items loaded significantly on their respective variable with standardized loadings $>0.70$ (Hair et al, 2005). Table 2 shows the scale summary with the mean, standard deviation, reliability and factor loading of all the scale items.

$<$ Insert Table 2 about here $>$

All the parameter estimates are large with significantly large t-values (9.8 to 30.6$)$ (Anderson and Gerbing, 1988) with all the item-to-total correlations (0.71 to 0.95) and average variance extracted ( 0.65 to 0.91 ) higher than 0.5 , showing high convergent validity (Fornell and Larcker, 1981). Finally, discriminant validity is confirmed as the average variance extracted in each factor exceeds its squared correlations with all other constructs (Fornell and Larcker, 1981). We next examined the squared multiple correlations of all the scale items and eliminated four items with values of less than 0.40 (Nunnally, 1978). The revised model provided a reasonably good fit to the data $($ Chi-square $=1165.2$, degrees of freedom $=634, p<0.000 ;$ CFI $=0.93$, TLI $=$ $0.93, \mathrm{IFI}=0.93, \mathrm{SRMR}=0.078$ and $\mathrm{RMSEA}=0.067)$.

Finally, we used the structural model to test all the hypotheses. For H1, we found that perceived physical attractiveness has a positive relationship with salesperson's extra role (H1b, $\beta$ $=0.172 ; \mathrm{p}<0.05)$ and need identification $(\mathrm{H} 1 \mathrm{c}, \beta=0.063 ; \mathrm{p}<0.10)$ behaviors but not service manner (H1a). Similarly for $\mathrm{H} 2$, communication ability has a positive relationship with only service manner $(\mathrm{H} 2 \mathrm{a}, \beta=0.325 ; \mathrm{p}<0.001)$ and need identification $(\mathrm{H} 2 \mathrm{c}, \beta=0.303 ; \mathrm{p}<0.001)$ 
but not extra role $(\mathrm{H} 2 \mathrm{~b})$ behaviors of the salesperson. For H3, we found positive relationship between perceived expertise and service manner $(\mathrm{H} 3 \mathrm{a}, \beta=0.359 ; \mathrm{p}<0.001)$, extra role $(\mathrm{H} 3 \mathrm{~b}, \beta$ $=0.347 ; \mathrm{p}<0.001)$ as well as need identification $(\mathrm{H} 3 \mathrm{c}, \beta=0.148 ; \mathrm{p}<0.05)$. For $\mathrm{H} 4$, we found a significant positive relationship between perceived trustworthiness and service manner $(\mathrm{H} 4 \mathrm{a}, \beta=$ $0.183 ; \mathrm{p}<0.01)$ and need identification $(\mathrm{H} 4 \mathrm{c}, \beta=0.304 ; \mathrm{p}<0.001)$ but not with extra role behavior (H4b). Thus, we found mixed support for H1, H2 and H4 and full support for H3.

For the next set of hypotheses, we tested the influence of the three service behaviors on three customer outcomes. For H5, we found that customer's willingness to disclose personal information was influenced by the salesperson's service manner but in a negative direction (H5a, $\beta=-0.860 ; p<0.001)$, contrary to our hypothesis. However, customer's perception about the salesperson's extra role behavior $(\mathrm{H} 5 \mathrm{~b}, \beta=0.281 ; \mathrm{p}<0.01)$ as well as need identification had a strong positive effect on their willingness to disclose (H5c, $\beta=0.837 ; p<0.001)$. Interestingly, customer satisfaction was influenced by only need identification $(\mathrm{H} 6 \mathrm{c}, \beta=.931, \mathrm{p}<.001)$ and not service manner (H6a) or extra role behavior (H6b). Similarly, behavioral intention was affected only by need identification $(\mathrm{H} 7 \mathrm{c}, \beta=.932, \mathrm{p}<.001)$ and not by service manner $(\mathrm{H} 7 \mathrm{a})$ or extra role (H7b) behaviors. Hence, we got only partial support for H5, H6 and H7.

$<$ Insert Table 3 about here $>$

\section{DISCUSSION}

In this study, we examine two sets of influences in an adaptive selling context. First, we assessed the impact of four salesperson's attributes as perceived by their customers (physical attractiveness, communication ability, expertise and trustworthiness) on their perceptions about 
three types of service behaviors (service manner, extra role and need identification). Second, we explored the influence of customer perceptions about service behaviors on three important customer outcomes (willingness to disclose personal information, customer satisfaction and behavioral intentions). In order to explore these relationships, we used a field-survey design with actual customers in a real business environment, namely retail telecom outlets in Hong Kong.

The results from our field-survey seem to provide a preliminary support to our basic premise as mentioned above. Specifically, we found that among all the four salesperson characteristics included in our study, only their perceived expertise seems to affect customer perceptions about all the three types of their subsequent service behaviors; whereas the other three characteristics (physical attractiveness, communication ability and trustworthiness) only affect some of the subsequent customer perceptions. This is an interesting finding because in the context of retail telecom services, the customers may rely more on the perceived expertise (as reflected in their knowledge about various plans and offers, availability of the network in different locations and its technical aspects) rather than how good the salesperson looks or how well s/he talks. Moreover, even trustworthiness does not seem to be a very important variable as the service encounters happen in the retail outlets of a reputed and trusted telecom company in Hong Kong and all the salespersons are known to represent this company.

A further look at the strength of associations among the four salesperson characteristics with each other shows that the association between perceived communication ability and trustworthiness is much stronger compared to physical attractiveness and expertise. This finding may be particularly useful in the adaptive selling environment wherein it seems that rather than only look good, the salespersons should also demonstrate their ability to identify their customers' needs, show good communication skills throughout the interaction process, possess the required 
knowledge and expertise about the products and service handled by them, and present themselves as a trustworthy salesperson. This may help them customize their sales presentation and recommend products and services that satisfy a particular customer's specific requirements.

After the initial contact, the salespersons serve the customer and identify the products and services that best fits customer needs. For example, they may recommend either a home broadband or a wireless broadband service in respond to a customer's internet service enquiry, since both services offer broadband access. To achieve higher successful rate by introducing the key benefits that appeal to that specific customer, the salesperson would customize the sales message before presenting to the customer. We argued that during this interaction, an evaluation and judgment process would take place, where the customer would evaluate the salesperson in terms of his/her attitude and performance, and their own satisfaction level. Specifically, we hypothesized that the three types of service behaviors (service manner, extra role and need identification) of the salesperson would affect customer evaluation and judgments.

Our findings show that customers' perceptions about the salesperson's service behavior play an important role on how they evaluate their shopping experience and their subsequent behavioral intentions towards the salesperson and the company. Specifically, our result show that extra role and need identification behaviors of the salesperson have a positive influence on the customer's willingness to disclose personal information, whereas perceived service manner is negatively associated with disclosure. While the first two findings are as expected, the third finding is somewhat counter-intuitive as we hypothesized service manner to also have a positive effect on customer's willingness to disclose personal information to facilitate the selling process. However, prior research also shows that customers find it rather risky to disclose their personal information to salespeople (Luo, 2002). Others argue that people tend to disclose to those whom 
they trust and like, which may not be true with salespersons (Jourard 1964; Worthy et al. 1969).

Willingness to disclose is a key element of adaptive sales as well as the customer's evaluation and judgment processes. A salesperson's ability to elicit personal information from customer is critical in adaptive sales, so that they can change their sales messages dynamically based on customer needs. By knowing more about customer's expectation and the services they need, salesperson can identify the appropriate products and service from the company's service offerings, and to prepare more customized selling scripts and messages to present to customers. This is probably why in our study; service manner (a seemingly superficial act by the salesperson) did not have a significant influence, unlike extra role and need identification behaviors (which are possibly considered more relevant and meaningful by the customers).

Similarly, we found that only customer's perception about the salesperson's need identification behavior (and not service manner and extra role) have a strong positive influence on customer satisfaction. In other words, if customers perceive that the salesperson is able to correctly identify their needs, they are likely to evaluate their shopping experience more positively resulting in a higher level of satisfaction. This is particularly true in adaptive selling environment where salesperson should adjust their sales presentation to recommend products and services that meet customers need. Hence, it is more important that salespersons should demonstrate their ability to proactively identify customer's needs rather than just show courtesy and politeness, which may be perceived as superficial or unimportant by the customers.

Finally, we found that both perceived extra role and need identification behaviors of the salesperson have a positive impact on customer's behavioral intentions. Specifically, customers who perceive the salesperson to make extra efforts to serve them and identify their needs are more likely to purchase from them and patronize them again. This is also an important finding 
because it shows a direct link between customer perceptions about a salesperson's extra role and need identification behaviors and their own behavioral intentions. Therefore, managers would find it useful to train their frontline sales and service employees to learn these important skills. Interestingly, salesperson's service manner behavior again does not seem to be important enough to have a significant impact on customers' behavioral intentions.

Overall, our research highlights that in today's increasingly complex and competitive marketplace, managers need to understand that it is not enough to hire good looking frontline sales and service employees with good communication skills; instead they also need to help their employees develop the expertise needed to do their job and address customers' queries so as to develop trustworthiness, especially in an adaptive sales context. Moreover, it is not enough for the frontline employees to be well-dressed, well-mannered and polite; but they also need to make the extra efforts to understand and satisfy their customers' actual needs, which makes their customers more willing to disclose their personal information, to be more satisfied and more likely to make the purchase and patronize again, possibly becoming loyal customers over time.

Our study has some limitations that future research may address. First, our study was conducted in a single service industry in a single city hence our model can be tested in diverse research and cultural settings. Future research may also include other salesperson characteristics such as their personality traits and cultural orientations. Finally, we study only the customers' perspective in this study, hence it would be useful to the employees' point of view as well. 


\section{REFERENCES}

Ahearne, M., Gruen, T.W. and Jarvis, C.B. (1999), "If looks could sell: Moderation and mediation of the attractiveness effect on salesperson performance", International Journal of Research in Marketing, Vol. 16 No. 4, pp. 269-284.

Anderson, E.W. and Sullivan, M.W. (1993), "The antecedents and consequences of customer satisfaction for firms", Marketing Science, Vol. 12 No. 2, pp. 125-143.

Anderson, J.C. and Gerbing, D.W. (1988), “An Updated Paradigm for Scale Development Incorporating Unidimensionality and Its Assessment", Journal of Marketing Research, Vol. 25 No. 2, pp. 186-192.

Anderson, R. (1995), Essentials of Personal Selling: The New Professionalism, PrenticeHall, Englewood Cliffs, NJ.

Baranes, E. and LeBlanc, G. (2006), "Bundling strategies in ICT sector: An introduction", Communication \& Strategies, Vol. 14 No. 63, pp. 13-18.

Berry, L.L., Parasuraman, A. and Zeithaml, V.A. (1994), "Improving service quality in America: Lessons learned”, Academy of Management Executive, Vol. 8 No. 2, pp. $32-45$.

Bettencourt, L.A. and Brown, S.W. (1997), "Contact Employees: Relationships Among Workplace Fairness, Job Satisfaction and Prosocial Service Behaviors", Journal of Retailing, Vol. 73 No. 1, pp. 39-61. 
Bitner, M.J. (1995), “Building Service Relationship: It's all about promises”, Journal of the Academy of Marketing Science, Vol. 23 No. 4, pp. 246-251.

Boorom, M.L., Goolsby, J.R. and Ramsey, R.P. (1998), "Relational communication traits and their effect on adaptiveness and sales performance", Journal of the Academy of Marketing Science, Vol. 26 No. 1, pp. 16-30.

Cho, J. (2006), "The mechanism of trust and distrust formation and their relational outcomes", Journal of Retailing, Vol. 82 No. 1, pp. 25-35.

Collins, N.L. and Miller, L.C. (1994), "Self-Disclosure and Liking: A Meta-analytic Review”, Psychological Bulletin, Vol. 116 No. 3, pp. 457-475.

Coulter, K.S. and Coulter, R.A. (2003), "The effects of industry knowledge on the development of trust in service relationships", International Journal of Research in Marketing, Vol. 20 No. 1, pp. 31-43.

Deighton, J. (1996), “The Future of interactive marketing”, Harvard Business Review, Vol. 74 No. 6, pp. 151-161.

Dion K., Berscheid E. and Walster E. (1972), "What is beautiful is good", Journal of Personality and Social Psychology, Vol. 24 No. 3, pp. 285-290.

Dwyer, F. R., Schurr, P.H., and Oh, S. (1987), "Developing Buyer-Seller Relationships”, Journal of Marketing, Vol. 51 No. 2, pp. 11-27. 
Eagly, A.H., Ashmore, R.D., Makhijani, M.G. and Longo, L.C. (1991), "What is beautiful is good, but...: A meta-analytic review of research on the physical attractiveness stereotype", Psychological Bulletin, Vol. 110 No. 1, pp. 109-128.

Fornell, C. and Larcker, D.F. (1981), "Evaluating Structural Equation Models with Unobservable Variables and Measurement Error", Journal of Marketing Research, Vol. 18 No. 1, pp. 39-50.

Franke, G. R. and Park, J.E. (2006), "Salesperson adaptive selling behavior and customer orientation: a meta-analysis", Journal of Marketing Research, Vol. 43 No. 3, pp. $693-702$.

Webster, Frederick E. Jr. (1968), "Interpersonal Communication and Salesman Effectiveness", Journal of Marketing, Vol. 32 No. 3, pp. 7-18.

Grewal, D., Levy, M. and Kumar, V. (2009), “Customer Experience Management in Retailing: An Organizing Framework", Journal of Retailing, Vol. 85 No. 1, pp. 114.

Gulas, C.S. and McKeage, K. (2000), "Extending social comparison: an examination of the unintended consequences of idealized advertising imagery", Journal of Advertising, Vol. 24 No. 2, pp. 17-28.

Hair, J.F., Black, B., Babin, B., Anderson, R.E. and Tatham, R.L. (2005). Multivariate Data Analysis (6th Edition), Prentice Hall, Upper Saddle River, NJ.

Hatfield, E. and Sprecher, S. (1986), Mirror, Mirror: The Importance of looks in 
everyday life, SUNY Press, Albany, NY.

Hu, L.T. and Bentler, P.M. (1999), "Cutoff Criteria for Fit Indexes in Covariance Structure Analysis: Conventional Criteria Versus New Alternatives", Structural Equation Modeling, Vol. 6 No.1, pp. 1-55.

Hunter, G.K. and Perreault, W.D. (2006), "Sales Technology Orientation Information Effectiveness, and Sales Performance", Journal of Personal Selling \& Sales Management, Vol. 26 No. 2, pp. 95-113.

Jourard, S.M. (1964), The transparent self, Van Nostrand, Princeton, NJ.

Karmarkar, U. (2004), "Will you survive the services revolution”, Harvard Business Review, Vol. 82 No. 6, pp. 100-108.

Lloyd, A.E. and Luk, S.T.K. (2011), "Interaction behaviors leading to comfort in the service encounter”, Journal of Services Marketing, Vol. 25 No. 2, pp. 176-189.

Luo, X. (2002), "Trust Production and Privacy Concerns on the Internet: A Framework Based on Relationship Marketing and Social Exchange Theory”, Industrial Marketing Management, Vol. 31 No. 2, pp. 111-118.

Mattila, A.S. and Enz, C.A. (2002), "The Role of Emotions in Service Encounters", Journal of Service Research, Vol. 4 No. 4, pp. 268-277.

Nunnally, J.C. (1978), Psychometric theory (2nd edition), McGraw-Hill, New York, NY. 
O’Doherty, J., Winston, J., Critchley, H., Perrett, D., Burt, D.M. and Dolan, R.J. (2003), "Beauty in a smile: the role of medial orbitofrontal cortex in facial attractiveness", Neuropsychologia, Vol. 41 No. 2, pp. 147-155.

Parasuraman, A., Zeithaml, V.A. and Berry, L.L. (1985), “A conceptual model of service quality and its implications for future research", Journal of Marketing, Vol. 49 No. 4, pp. $41-50$.

Park, J.E. and Holloway, B.B. (2003), “Adaptive Selling Behavior Revisited: An empirical examination of learning orientation, sales performance and job satisfaction", Journal of Personal Selling \& Sales Management, Vol. 23 No. 3, pp. 239-251.

Podsakoff, P. M., Ahearne, M. and MacKenzie, S.B. (1997), “The Impact of Organizational Citizenship Behavior on Organizational Performance: A Review and Suggestions for Future Research”, Human Performance, Vol. 10 No. 2, pp. 133-151.

Podsakoff, P.M. and MacKenzie, S.B. (1994), “Organizational Citizenship Behaviors and Sales Unit Effectiveness”, Journal of Marketing Research, Vol. 31 No. 3, pp. 351363.

Price, L.L., Arnould, E.J. and Deibler, S.L. (1995), “Consumers Emotional response to service encounters: the influence of the service provider", International Journal of service Industry Management, Vol. 6 No. 3, pp. 34-63.

Pugh, S.D. (2001), "Service with a Smile: Emotional Contagion in the Service Encounter", Academy of Management Journal, Vol. 44 No. 5, pp. 1018-1027. 
Ramsey, R.P. and Sohi, R.S. (1997), "Listening to your customers: the impact of perceived salesperson listening behavior on relationship outcomes", Journal of the Academy of Marketing Science, Vol. 25 No. 2, pp. 127-137.

Roman, S. and Martin, P.J. (2008), "Changes in sales call frequency: a longitudinal examination of the consequences in the supplier-customer relationship", Industrial Marketing Management, Vol. 37 No. 5, pp. 554-564.

Roman, W.S. and Iacobucci, D. (2010), “Antecedents and consequences of adaptive selling confidence and behavior: a dyadic analysis of salespeople and their customers", Journal of the Academy Marketing Science, Vol. 38 No. 3, pp. 363-382.

Rust, R.T. and Oliver, R.L. (1994), "Service quality: insights and managerial implication from the Frontier", in Rust, R.T. and Oliver, R.L. (Eds), Service Quality: New Direction in Theory and Practice, Sage Publications, Thousand Oaks, CA, pp. 72-94.

Sirdeshmukh, D., Singh, J. and Sabol, B. (2002), "Consumer Trust, Value, and Loyalty in Relational Exchanges", Journal of Marketing, Vol. 66 No. 1, pp. 15-37.

Smith, J.B. and Barclay, D.W. (1997), “The Effects of Organizational Differences and Trust on the Effectiveness of Selling Partner Relationships", Journal of Marketing, Vol. 61 No. 1, pp. 3-21.

Spiro, R.S. and Weitz, B.A. (1990), “Adaptive selling: conceptualization, measurement, and nomological validity", Journal of Marketing Research, Vol. 27 No. 1, pp. 6169. 
Sujan, H., Weitz, B.A. and Kumar, N. (1994), "Learning orientation, working smart, and effective selling”, Journal of Marketing, Vol. 58 No. 3, pp. 39-52.

Verbeke, W., Dietz, B. and Verwaal, E. (2011), "Drivers of sales performance: a contemporary meta-analysis. Have salespeople become knowledge brokers?" Journal of the Academy of Marketing Science, Vol. 39 No. 3, pp. 407-428.

Weitz, B.A., Sujan, H. and Sujan, M. (1986), "Knowledge, motivation and adaptive behavior: a framework for improving selling effectiveness", Journal of Marketing, Vol. 50 No. 4, pp. 174-191.

White, T.B. (2004), “Consumer Disclosure and Disclosure Avoidance: A Motivational Framework", Journal of Consumer Psychology, Vol. 14 No. 1, pp. 41-51.

Winsted, K.F. (2000), "Service behaviors that lead to satisfied customers", European Journal of Marketing, Vol. 34 Nos. 3/4, pp. 399-417.

Worthy, M., Gary, A.L. and Kahn, G.M. (1969), "Self-disclosure as an exchange process", Journal of Personality and Social Psychology, Vol. 13 No. 1, pp. 59-63.

Zeithaml, V.A., Parasuraman, A. and Berry, L.L. (1985), "Problems and strategies in services marketing", Journal of Marketing, Vol. 49 No. 2, pp. 33-46.

Zeithaml, V.A., Berry, L.L. and Parasuraman, A. (1996), “The Behavioral consequences of service quality", Journal of Marketing, Vol. 60 No. 2, pp. 31-46. 
Figure 1 - Conceptual Model

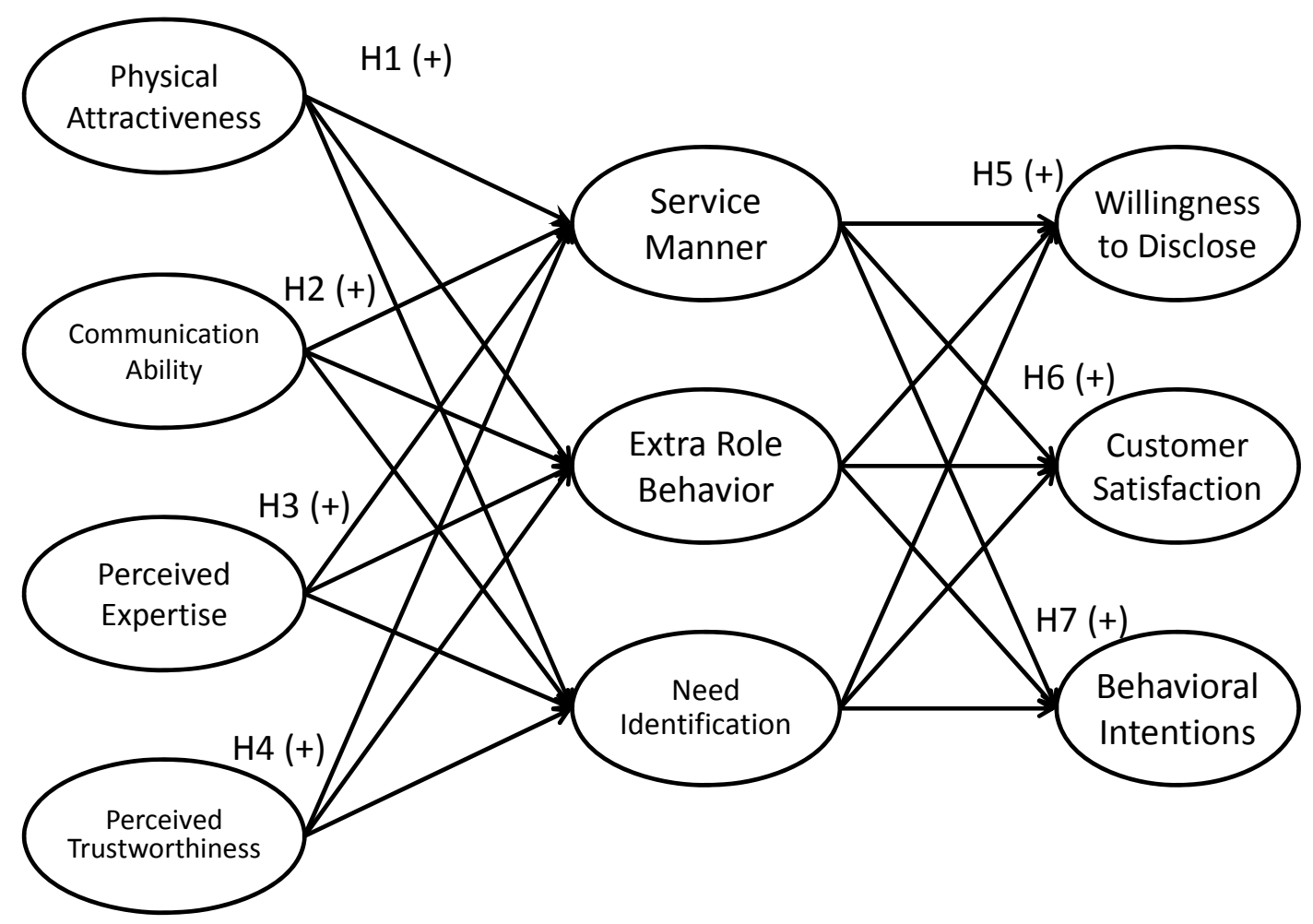


Table 1 - Sample Profile

\begin{tabular}{|c|c|c|c|}
\hline $\begin{array}{l}\text { Demographic/ } \\
\text { Control Variables }\end{array}$ & Category & $\begin{array}{c}\text { Frequency } \\
(\mathrm{N}=186)\end{array}$ & Percent \\
\hline \multirow[t]{2}{*}{ Nationality } & (1) Hong Kong SAR & 174 & $93.5 \%$ \\
\hline & (2) Mainland China & 12 & $6.5 \%$ \\
\hline \multirow[t]{2}{*}{ Gender } & (1) Male & 96 & $51.6 \%$ \\
\hline & (2) Female & 90 & $48.4 \%$ \\
\hline \multirow[t]{5}{*}{ Age } & $(1)<20$ 以下 & 7 & $3.8 \%$ \\
\hline & (2) $20-29$ & 58 & $31.2 \%$ \\
\hline & (3) $30-39$ & 57 & $30.6 \%$ \\
\hline & (4) $40-49$ & 40 & $21.5 \%$ \\
\hline & (5) $50 \geq$ 以上 & 24 & $12.9 \%$ \\
\hline \multirow[t]{4}{*}{ Education } & (1) $\leq$ Secondary School & 85 & $45.7 \%$ \\
\hline & (2) College & 60 & $32.3 \%$ \\
\hline & (3) $>$ College & 25 & $13.4 \%$ \\
\hline & (4) Others & 16 & $8.6 \%$ \\
\hline \multirow[t]{10}{*}{ Occupation } & (1) Technician/blue-collar & 11 & $5.9 \%$ \\
\hline & (2) Professional & 30 & $16.1 \%$ \\
\hline & (3) Manager/Executive & 20 & $10.8 \%$ \\
\hline & (4) Salespersons & 36 & $19.4 \%$ \\
\hline & (5) Self-employed & 17 & $9.1 \%$ \\
\hline & (6) Civil servant & 22 & $11.8 \%$ \\
\hline & (7) Housewife & 27 & $14.5 \%$ \\
\hline & (8) Student & 6 & $3.2 \%$ \\
\hline & (9) Retiree/unemployed & 8 & $4.3 \%$ \\
\hline & (10) Others & 9 & $4.8 \%$ \\
\hline Monthly Household & (1) $\leq \mathrm{HK} \$ 10,000$ 以下 & 39 & $21 \%$ \\
\hline \multirow[t]{2}{*}{ Income } & (2)HK\$10,001-\$30,000 & 121 & $65.1 \%$ \\
\hline & (3) $\geq \mathrm{HK} \$ 30,001$ 以上 & 26 & $14 \%$ \\
\hline \multirow[t]{2}{*}{ Visit Purpose } & Make an enquiry & 105 & $56 \%$ \\
\hline & Make a purchase & 81 & $44 \%$ \\
\hline Overall Impression & High Impression & 104 & $56 \%$ \\
\hline of the shop & Low impression & 82 & $44 \%$ \\
\hline
\end{tabular}




\begin{tabular}{lcccc}
\hline & Factor & Mean & & Item-to- \\
Scale Items & loadings & (M) & SD & total \\
& & & correlation \\
\hline
\end{tabular}

Perceived Attractiveness (Ahearne et al., 1999) - Reliability $(\boldsymbol{\alpha})=0.85$

1. Is very good-looking

$\begin{array}{llll}0.93 & 5.67 & 1.09 & 0.81\end{array}$

2. Has an attractive appearance

$\begin{array}{llll}0.94 & 5.54 & 1.12 & 0.85\end{array}$

3. Would generally be thought of as beautiful / handsome

$0.76 \quad 5.34 \quad 1.10$

0.73

Communication Ability (Ahearne et al., 1999) - Reliability ( $\alpha)=0.85$
4. Wastes time talking about unimportant issues
0.65
$6.17 \quad 0.95$
0.60
5. Listens to my needs / concerns
0.88
$6.00 \quad 1.04$
0.77
6. Tailors his / her presentations to my need
0.87
$6.1 \quad 0.94$
0.75

Perceived Expertise (Ahearne et al., 1999) - Reliability $(\boldsymbol{\alpha})=0.92$

7. Understands my needs

$\begin{array}{llll}0.80 & 6.05 & 1.06 & 0.76\end{array}$

8. Is an excellent source of information about the

$\begin{array}{lll}0.95 & 6.05 & 0.92\end{array}$

0.89 products/services he / she represents

$\begin{array}{llllll}\text { 9. Is able to recommend products and service for dealing } & & 0.87 & 6.04 & 0.91 & 0.82\end{array}$ with difficult cases

10. Is knowledgeable about the products and services

$\begin{array}{llll}0.87 & 6.08 & 0.93 & 0.84\end{array}$

Perceived Trustworthiness (Ahearne et al., 1999) - Reliability $(\alpha)=0.78$
11. Is always honest in his/her dealings with me
0.85
$\begin{array}{ll}6.10 & 1.01\end{array}$
0.71
12. Is someone I feel I can trust
0.91
$\begin{array}{ll}6.18 & 0.88\end{array}$
0.76
13. Never tries to mislead me
0.65
$5.80 \quad 1.38$
0.57

Willingness to disclose personal information $(\mathrm{Cho}, \mathbf{2 0 0 6})-$ Reliability $(\boldsymbol{\alpha})=0.91$

14. I am willing to provide my personal information when

0.89

$5.68 \quad 1.39$

0.83 asked by this sales representative

15. I am willing to disclose even sensitive personal

$\begin{array}{llll}0.88 & 5.27 & 1.57 & 0.84\end{array}$
information to this sales representative for the purpose of fulfilling my order

16. I am willing to be truthful in revealing my personal information to this sales representative

\section{Customer satisfaction (Ramsey and Sohi 1997) - Reliability $(\alpha)=0.91$}
17. The amount of contact I have had with this salesperson
0.74
7.93
1.73
0.72 was adequate 
18. I am satisfied with the level of service this person has $\begin{array}{llll}0.97 & 8.50 & 1.38 & 0.87\end{array}$ provided

19. In general, I am pretty satisfied with my dealings with $\begin{array}{lll}0.97 & 8.58 & 1.37\end{array}$

0.88 this salesperson

Behavioral intentions (Ramsey and Sohi, 1997) - Reliability $(\boldsymbol{\alpha})=0.98$

20. It is probable that I will contact this salesperson again $\begin{array}{lll}0.92 & 8.40 & 1.64\end{array}$ 0.93

21. I am willing to discuss business with this salesperson $\begin{array}{llll}0.93 & 8.48 & 1.61 & 0.94\end{array}$ again

22. I plan to continue doing business with this salesperson $\begin{array}{llll}0.98 & 8.41 & 1.61 & 0.95\end{array}$

23. I will purchase from this salesperson again

$0.98 \quad 8.41 \quad 1.61$

0.95

Service Manner Behavior (Lloyd and Luk, 2011) - Reliability $(\alpha)=0.95$

24. The service employee showed patience

0.91

$6.17 \quad 0.82$

0.86

25. The service employee was helpful

0.88

$6.17 \quad 0.88$

0.85

26. The service employee smiled at me

0.82

$6.16 \quad 0.91$

0.83

27. The service employee was polite

0.84

$\begin{array}{ll}6.30 & 0.81\end{array}$

0.82

28. The service employee was relaxing to interact with

0.82

$\begin{array}{ll}6.16 & 0.97\end{array}$

0.80

29. The service employee showed passion for their job

0.78

$6.15 \quad 0.84$

0.78

30. The service employee was cheerful

0.78

$\begin{array}{ll}6.13 & 0.87\end{array}$

0.78

Need identification Behavior (Lloyd and Luk, 2011) - Reliability $(\alpha)=0.85$
31. The service employee understood my needs
0.75
6.160 .88
0.71
32. The service employee was knowledgeable
0.76
$\begin{array}{ll}6.20 & 0.87\end{array}$
0.71
33. The service employee anticipated my needs
0.84
$6.09 \quad 0.84$
0.71

Extra-Role Service Behavior (Bettencourt and Brown, 1997) - Reliability $(\boldsymbol{\alpha})=0.94$

34. Voluntarily assists customers even if it means going

0.76 5.62

1.13 0.75 beyond job requirements.

35. Helps customers with problems beyond what is expected or required

36. Often goes above and beyond the call of duty when serving customers

37. Willingly goes out of his/her way to make a customer satisfied

38. Frequently goes out the way to help a customer

0.8

0.91

5.4

0.91

5.65

1.14

0.87

0.95 
Table 3 - Hypotheses and Results Summary

\begin{tabular}{|c|c|c|c|c|c|}
\hline \multirow{2}{*}{$\begin{array}{c}\text { Hypo } \\
\# \\
\text { H1a }\end{array}$} & \multicolumn{3}{|c|}{ Hypothesized Relationship } & \multirow{2}{*}{$\begin{array}{c}\begin{array}{c}\text { Std. beta } \\
\text { Coeff. }\end{array} \\
0.022\end{array}$} & \multirow{2}{*}{$\begin{array}{c}\text { Results } \\
\text { NS }\end{array}$} \\
\hline & Physical Attractiveness & $\rightarrow$ & Service Manner & & \\
\hline $\mathrm{H} 1 \mathrm{~b}$ & Physical Attractiveness & $\rightarrow$ & Extra Role & $0.172 *$ & Supported \\
\hline $\mathrm{H} 1 \mathrm{c}$ & Physical Attractiveness & $\rightarrow$ & Need Identification & $0.063 \#$ & Supported \\
\hline $\mathrm{H} 2 \mathrm{a}$ & Communication Ability & $\rightarrow$ & Service Manner & $0.325 * * *$ & Supported \\
\hline $\mathrm{H} 2 \mathrm{~b}$ & Communication Ability & $\rightarrow$ & Extra Role & 0.155 & NS \\
\hline $\mathrm{H} 2 \mathrm{c}$ & Communication Ability & $\rightarrow$ & Need Identification & $0.303 * * *$ & Supported \\
\hline $\mathrm{H} 3 \mathrm{a}$ & Expertise & $\rightarrow$ & Service Manner & $0.359 * * *$ & Supported \\
\hline $\mathrm{H} 3 \mathrm{~b}$ & Expertise & $\rightarrow$ & Extra Role & $0.347^{*}$ & Supported \\
\hline $\mathrm{H} 3 \mathrm{c}$ & Expertise & $\rightarrow$ & Need Identification & $0.148^{*}$ & Supported \\
\hline $\mathrm{H} 4 \mathrm{a}$ & Trustworthiness & $\rightarrow$ & Service Manner & $0.183^{* *}$ & Supported \\
\hline $\mathrm{H} 4 \mathrm{~b}$ & Trustworthiness & & Extra Role & 0.087 & NS \\
\hline $\mathrm{H} 4 \mathrm{c}$ & Trustworthiness & $\rightarrow$ & Need Identification & $0.304 * * *$ & Supported \\
\hline $\mathrm{H} 5 \mathrm{a}$ & Service Manner & $\rightarrow$ & Willingness to Disclose & $-0.860 * *$ & Supported \\
\hline $\mathrm{H} 5 \mathrm{~b}$ & Extra Role & $\rightarrow$ & Willingness to Disclose & $0.281 * *$ & Supported \\
\hline $\mathrm{H} 5 \mathrm{c}$ & Need Identification & $\rightarrow$ & Willingness to Disclose & $0.837 * * *$ & Supported \\
\hline H6a & Service Manner & $\rightarrow$ & Customer satisfaction & -0.198 & NS \\
\hline $\mathrm{H} 6 \mathrm{~b}$ & Extra Role & & Customer satisfaction & 0.070 & NS \\
\hline H6c & Need Identification & $\rightarrow$ & Customer satisfaction & $0.954 * * *$ & Supported \\
\hline $\mathrm{H} 7 \mathrm{a}$ & Service Manner & $\rightarrow$ & Behavioral intentions & -0.181 & NS \\
\hline $\mathrm{H} 7 \mathrm{~b}$ & Extra Role & $\rightarrow$ & Behavioral intentions & $0.207 * *$ & Supported \\
\hline $\mathrm{H} 7 \mathrm{c}$ & Need Identification & $\rightarrow$ & Behavioral intentions & $0.932 * * *$ & Supported \\
\hline
\end{tabular}

$\# \mathrm{p}<0.10, * \mathrm{p}<0.05, * * \mathrm{p}<0.01, * * * \mathrm{p}<0.001$, all two-tailed

NS $=$ Not Supported 